\title{
The Relationship between HDI Values and Road Traffic Fatality Rates
}

\author{
Salih Gökberk Düzyol ${ }^{1}$, Kaan Daibaşoğlu² ${ }^{2}$ Yeşim Üzümcüoğlu ${ }^{3}$
}

Düzyol, S. G., Daibaşoğlu, K., \& Üzümcüoğlu, Y. (2021). The relationship between HDI values and road traffic fatality rates. Nesne, 9(19), 42-51. DOI: 10.7816/nesne-09-19-04

\section{Keywords}

Human Development Index, road safety, road traffic fatalities, traffic fatality rates

\author{
Anahtar kelimeler \\ İnsan Gelişmişlik \\ Endeksi, yol güvenliği, \\ karayolu trafik \\ ölümleri, trafik ölüm \\ oranlar1
}

\begin{abstract}
Road traffic accidents are a serious but an avoidable problem that cause both life and economic loss worldwide. There are some common factors such as income, education and health that affect both socioeconomic development and road traffic fatality rates of countries. Examination of these factors separately during the analyze of road traffic fatality rates might cause misleading results due to the relationships between stated variables. Thus, using an inclusive parameter like Human Development Index (HDI), may provide more realistic results. In the current study, the relationship between HDI, its dimensions (GNI per capita, expected years of schooling, mean years of schooling and life expectancy at birth) and road traffic fatality rates are examined. Hierarchical regression analysis was conducted in order to obtain results about the effects of each dimension of HDI. Results showed that all dimensions of HDI negatively predicted road traffic fatalities. Results have been discussed according to related literature and suggestions have been made for further research and applications.
\end{abstract}

\section{IGE Değerleri ve Karayolu Trafik Ölüm Oranları Arasındaki İlişkinin İncelenmesi}

$\ddot{O} z$

Trafik kazaları dünya çapında yaşam kayıplarına ve ekonomik kayıplara neden olan ciddi ancak önlenebilir sorunlardır. Sağlık, eğitim ve gelir gibi faktörler de ülkelerin sosyoekonomik gelişmişlik düzeylerini ve trafik kazaları ölüm oranlarını etkileyen faktörlerdendir. Karayolu trafik ölüm oranlarının analizi sırasında bu faktörlerin ayrı ayrı incelenmesi, belirtilen değişkenler arasındaki ilişkilerden dolayı yanıltıcı sonuçlara neden olabilir. İnceleme yaparken İnsan Gelişmişlik Endeksi (IGE) gibi kapsayıcı bir parametre kullanmak daha realistik sonuçlar elde etmemize olanak sağlar. Bu çalışmada İGE endeksi, İGE endeksinin her bir boyutu (kişi baş1 gayrisafi milli hasıla, beklenen eğitim görme yılı, ortalama eğitim alınan yıl ve doğumdaki yaşam beklentisi) ve ölümlü trafik kazaları ile arasındaki ilişki incelenmiştir. İGE endeksinin her bir boyutunun etkilerini inceleyebilmek amacıyla hiyerarşik regresyon analizi kullanılmıştır. Sonuçlara göre İGE'nin tüm boyutları, karayolu trafik ölüm oranlarını negatif bir ilişki içerisinde tahmin etmektedir. Sonuçlar ilgili literatür ışığında tartışılmış ve uygulamalar ve gelecek çalışmalar için önerilerde bulunulmuştur.

Article History

Arrived: September 10, 2020

Revised: December 18, 2020

Accepted: January 24, 2021

DOI: 10.7816/nesne-09-19-04

\footnotetext{
${ }^{1}$ Psychology Student, TOBB University of Economics and Technology, Department of Psychology, sduzyol(at)etu.edu.tr, ORCID: 0000-0002-7037-8055

${ }^{2}$ Psychology Student, TOBB University of Economics and Technology, Department of Psychology, kdaibasoglu(at)etu.edu.tr, ORCID: 0000-0002-4385-3340 ${ }^{3}$ Asst. Prof., TOBB University of Economics and Technology, Department of Psychology, yzihni(at)etu.edu.tr, ORCID: 0000-0002-4905-5518
} 
According to the World Health Organization (WHO), even though the stable ratio of 18 road traffic fatalities (RTFs) per 100,000 population through years, an increasing trend has been observed in the number of traffic victims arriving at 1.35 million fatalities in 2016 as a consequence of increasing population (WHO, 2018a). In 2016, road traffic injuries (RTIs) was reported as the 5th leading cause of disability adjusted life years lost worldwide (WHO, 2018b), the 8th leading cause of fatalities for all ages (WHO, 2018a), and the leading cause of death for the age group between 5 to 29 years old (who are considered as children and young adults) (WHO, 2018a). The issue of road traffic accidents is a global problem affecting not only the health of people, but also the economy of countries. Wangdi et. al (2018) claimed that, approximately $3 \%$ of the gross national product is lost because of road traffic accidents.

Not every country suffers from traffic fatalities in the same severity as others. There are several factors that might prevent both accidents and their consequences (e.g. injuries, fatalities). Despite having $60 \%$ of the world's vehicles, more than $90 \%$ of RTFs occur in low and middle-income countries (WHO, 2020). In 2000, van Beeck, Borsboom, and Mackenbach also described the influence of economic development of a country on road safety. Although there are some exceptions such as Spain and Greece, economic growth first leads to a growing number of RTFs especially for low-middle income countries due to expanding rate of motor vehicles. After a critical point, it becomes more protective with in-vehicle measures of safety and investments on road traffic environment that minimizes risk (van Beeck et al., 2000). In other words, initially, increased income causes higher RTF risk briefly until the environment for safe drive and traffic safety culture is adopted in low-middle income countries. After a certain point, fatality risk decreases as a consequence of investments that are made for substructure of roads and transportation, enacted traffic laws while motor vehicles become a part of daily life, and safer vehicles by courtesy of technology. Supporting that, number of empirical studies has shown that RTFs increase as a country develops until a certain threshold where it starts to decline (Anbarci, Escaleras, \& Register,2009; Bishai, Quresh, James, \& Ghaffar, 2006; Garg \& Hyder, 2006; Kopits \& Cropper, 2005; Law, Noland, \& Evans, 2011). However, there are also studies, which were conducted at national level, that indicate a negative relationship between gross national income and RTF (Gaygısız, 2010; Özkan \& Lajunen, 2007).

Having an association with economic status, there are other factors like education and healthcare systems that play important roles in RTFs. To illustrate, the relationship between lower educational fulfilment and a higher risk of RTI due to unsafe driving behavior such as drunk driving, decreased use of seat belts and increased exposure to traffic and its risk has been supported by previous research (Cubbin, LeClere, \& Smith, 2000; Eun, 2020; Spoerri, Egger, \& von Elm,, 2011). While increasing the awareness of drivers about importance of obeying rules, better education also leads to better medical technology and emergency physicians. Qualified physicians with adequate equipment provide better post-accident intervention which is vital. Noland (2003) indicates that higher levels of physicians per capita is significantly associated with reduced total traffic fatalities. Evaluating the decline of RTFs in Korea, Kim et al. (2012) point out the development of the emergency medical services system to enhance post-accident response in the mid-1990s.

As mentioned above, economic status, education level of a country and adequate healthcare system are all related factors that influence RTF rates. Thus, an inclusive parameter that contains all three might provide a wider perspective and more realistic results. One of the most widely used measures of the comparative status of socioeconomic development across countries is Human Development Index (HDI). The HDI measures the socioeconomic levels of countries by taking into account their health, education and 
adjusted real income per capita. In 2010, measurement of HDI modified and in the current study, "HDI" mentions the latest version, which is also known as "New HDI" (Todaro \& Smith, 2015).

The HDI values of countries range between 0 and 1 . These values help us to rank countries from lowest to highest developed. As it is stated above three end products of development (i.e. health, education, and adjusted real income per capita) are used to calculate HDI. Health is measured by life expectancy at birth. Education is measured by combination of expected years of schooling and mean years of schooling of people who are older than 25. Lastly, a decent standard of living is measured by gross national income (GNI) per capita.

While computing HDI values, two steps are followed. First, for each end product of development, a "dimension index" is calculated. Second, HDI value is calculated by taking the geometric mean of these dimension indexes. Final HDI values can be categorized into four groups, which are low $(0.0-0.535)$, medium (0.536 - 0.711), high (0.712 - 0.799) and very high (0.8 - 1.0) (United Nations Development Program [UNDP], 2020a).

In the current study, the relationship between development level of countries and RTF rates is investigated. In addition, the relationships between the dimensions of HDI (i.e. health, education, and adjusted real income per capita) and their relationships with RTF rates are investigated. All parameters are expected to be in a negative relationship with RTF rates.

\section{Method}

\section{Datasets}

In the present study, The New HDI values is used as a measure of development. UNDP's data is used since they are the both the creator and the calculator of the index (UNDP, 2020b). HDI allows us to see the different human development outcomes of two countries with the same GNI per capita since it regards three key dimensions: long and healthy life, decent standard of living, and being knowledgeable. HDI values includes information about life expectancy at birth, mean years of schooling, expected years of schooling, GNI per capita and GNI per capita rank minus HDI rank. The present study does not include GNI per capita rank minus HDI rank to its investigation since it gives information about the difference between wealth and general HDI ranking. As an additional information, positive values of this data state that the country has a better development score compared to its wealth. However, HDI simplifies the needs of development and it cannot reflect all of the criterions such as poverty, inequalities and empowerment (UNDP, 2020a).

As a measure of RTF rates, estimated RTF rates of countries per 100000 population is used. The estimation was calculated by WHO (2018a). The per 100000 population ratios is selected to decrease biases that can result due to population differences between countries.

While UNDP's (2020b) HDI data contains information for 189 countries, WHO's (2018) report includes data for 175 countries. Hence, the common countries that were included in both datasets were used, resulting in 171 matching countries without missing values. Estimated RTF rates for Hong Kong, China (SAR), Liechtenstein, Andorra, Bahrain, Brunei Darussalam, Palau, Bahamas, Saint Kitts and Nevis, Algeria, Saint Vincent and the Grenadines, Marshall Islands, State of Palestine, Nicaragua, Zambia, Haiti, Djibouti, Yemen and Sierra Leone could not be found in WHO's report. Moreover, San Marino, West Bank and Gaza Strip, Cook Islands and Somalia appeared to be missing in UNDP's data even though their estimated road fatality rates have been calculated by WHO. The HDI and RTF rates of the countries that are included in the current are presented in Appendix 1. 


\section{Data Analysis}

In order to analyze the stated relationships between HDI and RTF rates, hierarchical regression analysis is used. Hierarchical regression is decided because of the advantages it gives on multidimensional values such as HDI (Gustafson, 1997). In the current study, dimensions of HDI (GNI per capita, expected years of schooling, mean years of schooling and life expectancy at birth) are entered into 3-step hierarchical regression analysis. Although all dimensions are related to each other, dimensions are ranked from general to specific. GNI per capita is entered in the first step, since it directly affects other two dimensions. As mentioned before, without struggling to earn living, income increase creates a chance to maintain education and make it more qualified. Also, giving chance to invest in health technology increases the life expectancy. In the second step education dimension is entered in addition to income due to beneficial effects on drivers, environment and health workers. Finally, healthcare dimension was entered in the last step. All analyses were conducted by SPSS software (Statistical Packages for the Social Sciences, version 24.0).

\section{Results}

To examine the relationships between study variables, Pearson's $r$ correlation test was conducted. The results showed that, there is a strong negative relationship between HDI values and RTF rates $(r=-.75$, $p<.001)$. Among the dimensions of HDI, RTF rates was negatively related to GNI per capita $(r=-.57, p<$ $.001)$, life expectancy $(r=-.59, p<.001)$, expected years of schooling $(r=-.65, p<.001)$ and mean years of schooling $(r=-.62, p<.001)$. Results indicate that HDI value is positively related to GNI per capita $(r=-$ $.76, p<.001)$, life expectancy $(r=-.67, p<.001)$, expected years of schooling $(r=-.90, p<.001)$ and mean years of schooling $(r=-.82, p<.001)$. According to the results, GNI per capita has also positive relationships with life expectancy $(r=-.52, p<.001)$, expected years of schooling $(r=-.63, p<.001)$ and mean years of schooling $(r=-.57, p<.001)$. Additionally, the results show that there is a positive relationship between life expectancy and both expected years of schooling $(r=-.57, p<.001)$ and mean years of schooling $(r=-.63, p<.001)$. Lastly, expected years of schooling have shown positive relationship with mean years of schooling $(r=-.69, p<.001)$. To sum up, it can be stated that HDI value is positively correlated with all of its dimensions. Estimated RTF rates have negative relationship with HDI values and its all dimensions.

Table 1

Correlations Between Study Variables

\begin{tabular}{|c|c|c|c|c|c|}
\hline & 1 & 2 & 3 & 4 & 5 \\
\hline 1. TFR (per 100000$)$ & 1 & & & & \\
\hline 2. HDI Values & $-.75^{*}$ & 1 & & & \\
\hline 3. GNI per Capita (2011 PPP dolar) & $-.57^{*}$ & $.76^{*}$ & 1 & & \\
\hline 4. Life Expectancy at Birth (years) & $-.59^{*}$ & $.67^{*}$ & $.52^{*}$ & 1 & \\
\hline 5. Expected Years of Schooling (years) & $-.65^{*}$ & $.90^{*}$ & $.63^{*}$ & $.57^{*}$ & 1 \\
\hline 6. Mean Years of Schooling (years) & $-.62^{*}$ & $.82^{*}$ & $.57^{*}$ & $.63^{*}$ & $.69^{*}$ \\
\hline
\end{tabular}

Note: TFR: Traffic fatality rates; ${ }^{*} p<.001$. 
In the three-step hierarchical regression analysis, GNI per capita was entered as the independent variable. Results indicate that GNI per capita significantly predicted RTF rates $\left(R^{2}=.32, F(1,169)=79.68, p\right.$ $<.001)$. GNI per capita values are negatively related to RTF rates $(\beta=-.57, p<.001)$.

In the second step of the hierarchical regression analysis, the education dimension was used as the independent variable. Both expected years of schooling and mean years of schooling variables were entered to the regression. Results indicate that, expected years of schooling and mean years of schooling values significantly predicted RTF rates $\left(R^{2}=.50, F(3,167)=54.99, p<.001\right)$. Expected years of schooling $(\beta=-$ $.33, p<.001)$ and mean years of schooling $(\beta=-.28, p<.001)$ were negatively related to RTF rates.

In the last step of our hierarchical analysis, life expectancy values were included as the independent variable. Results show that the model significantly predicted RTF rates $\left(R^{2}=.523, F(4,166)=45.50, p<\right.$ $.001)$. Life expectancy was negatively related to RTF rates $(\beta=-.22, p<.01)$.

Table 2

Hierarchical Regression Analysis on Traffic Fatality Rates

\begin{tabular}{|c|c|c|c|c|c|c|c|}
\hline & Model & $R^{2}$ & $\Delta R^{2}$ & $F$ & $\beta$ & $t$ & $p$ \\
\hline \multirow[t]{2}{*}{$\overline{1}$} & & .32 & & 79.68 & & & \\
\hline & GNI per Capita (2011 PPP dolar) & & & & -.57 & -8.93 & .000 \\
\hline \multirow[t]{4}{*}{2} & & .50 & .18 & 29.30 & & & \\
\hline & GNI per Capita (2011 PPP dolar) & & & & -.20 & -2.75 & .007 \\
\hline & $\begin{array}{l}\text { Expected Years of Schooling } \\
\text { (years) }\end{array}$ & & & & -.33 & -3.94 & .000 \\
\hline & Mean Years of Schooling (years) & & & & -.28 & -3.57 & .000 \\
\hline \multirow[t]{5}{*}{3} & & .52 & .03 & 9.06 & & & \\
\hline & GNI per Capita (2011 PPP dolar) & & & & -.16 & -2.24 & .027 \\
\hline & $\begin{array}{l}\text { Expected Years of Schooling } \\
\text { (years) }\end{array}$ & & & & -.29 & -3.51 & .001 \\
\hline & Mean Years of Schooling (years) & & & & -.19 & -2.31 & .022 \\
\hline & Life Expectancy at Birth (years) & & & & -.22 & -3.01 & .003 \\
\hline
\end{tabular}

\section{Discussion}

The aim of the current study was to investigate the relationship between HDI values and RTF rates at national level. Thus, effect of development on traffic fatality rates was investigated under three dimensions of HDI. The results showed that all of the HDI dimensions have positive correlations with HDI values. Hence, higher HDI rankings present a more developed country. Results of the current study indicate that HDI values were negatively related to RTF rates. It can be claimed that, any increase in the socioeconomic level of a country might play an important role to decrease RTF rates. Increased road safety can be achieved by improving socioeconomic level of a country.

HDI values provide general information about development level of countries. In order to obtain more detailed results, relationship between subdimensions of HDI and RTFs is examined with a hierarchical regression analysis. According to the results, GNI per capita, expected years of schooling, mean years of schooling and life expectancy at birth variables significantly predicted RTF rates and they were negatively related as expected. Based on the literature (Üzümcüoğlu, Solmazer \& Özkan, 2020), as the income of country increases, the RTF rates decrease. Since GNI per capita has the maximum standardized coefficient 
compared to other dimensions, a country showing progress in its economy is most likely to have a decrease in RTF rates. Hence, high-income countries have the least rate of RTF.

Education, which is a more specific variable than GNI per capita, was also negatively related to RTF rates. It has been shown that education attainment is positively related with seat belt use, especially front seat belt use, and obeying rules (Taylor \& Daily, 2019). Effectiveness of seat belts on decreasing both RTFs and RTIs is undoubtable (Beck, Downs, Stevens, \& Sauber-Schatz, 2017; Høye, 2016). Consequently, more educated people are less likely to cause deathly accidents. However, road fatality rates are more delicate to the change in the expected years of schooling than mean years of schooling. It might take long time to make changes in education systems. In addition, countries have to put this on the agenda and budget the changes which requires considerable bureaucracy, effort and time. Also, specific traffic education at young ages probably ensures more conscient population in the middle and long term. Therefore, consistent education policies might play a crucial role against the death rates caused by traffic accidents.

Results also show that, an increase in the life expectancy, the most specific subdimension that is affected from both economy and education level, might reduce the road fatality rates. Life expectancy may be related with the country's health system and a better health system can prevent high fatality ratios in traffic accidents. Supporting the aforementioned findings of Kim et al. (2012), the results show that life expectancy at birth is negatively related with RTFs. By improving the health system, a healthier population with high life expectancy can be procured, and also traffic death rates can be decreased. Therefore, investment in health services is also important to stand against road traffic death rates. Political actions that aim to increase the GNI per capita, mean years of schooling or expected years of schooling/life helps to save more people who die from traffic accidents and we can reduce the road death rate.

To increase the road security, policymakers can primarily focus on education since both mean and expected years of education tend to move together. Improving the education system and adding some specific courses about traffic security may have positive returns in a long term. Also, more educated people may increase the GNI per capita since GNI calculation includes every citizen's income even if they are working abroad (Pan, 2017). Interventions to increase road safety are not confidential. Any country could decrease fatality rate by adapting policies implemented from the countries with high HDI value and low fatality rate.

The issue of RTFs is a global problem. Despite the Bester's (2001) study where HDI values entered as independent variable in a stepwise regression, a study that examines the relationship between RTFs and both HDI values and its subdimensions has never been done. Nonetheless, the findings of this study have to be seen in light of some limitations. The last HDI ranking has been given in UNDP's 2019 report and these ranking have been made by regarding 2018 values of countries (UNDP, 2020b). However, since the last report of WHO published in 2016, instead of the most recent HDI rankings the 2016 rankings have been used to ensure consistency. Analyzing the stated relationships and examine the possible changes between years as new data gathered is crucial in order to prove consistency. As WHO provides more up-to-date data, this study can be reconducted for upcoming years and analyzed comparatively. 


\section{References}

Anbarci, N., Escaleras, M., \& Register, C. A. (2009). Traffic fatalities: does income inequality create an externality. Canadian Journal of Economics/Revue Canadienne D'économique, 42(1), 244-266.

Beck, L. F., Downs, J., Stevens, M. R., \& Sauber-Schatz, E. K. (2017). Rural and urban differences in passenger-vehicle-occupant deaths and seat belt use among adults-United States, 2014. MMWR Surveillance Summaries, 66(17), 1-13.

Bester, C. J. (2001). Explaining national road fatalities. Accident Analysis \& Prevention, 33(5), 663-672.

Bishai, D., Quresh, A., James, P., \& Ghaffar, A. (2006). National road casualties and economic development. Health Economics, 15(1), 65-81.

Cubbin, C., LeClere, F. B., \& Smith, G. S. (2000). Socioeconomic status and injury mortality: ndividual and neighbourhood determinants. Journal of Epidemiology \& Community Health, 54(7), 517-524.

Eun, S. J. (2020). Trends in mortality from road traffic injuries in South Korea, 1983-2017: Joinpoint regression and age-period-cohort analyses. Accident Analysis \& Prevention, 134, 105325.

Garg, N., \& Hyder, A. A. (2006). Exploring the relationship between development and road traffic injuries: a case study from India. The European Journal of Public Health, 16(5), 487-491.

Gaygisız, E. (2010). Cultural values and governance quality as correlates of road traffic fatalities: a nation level analysis. Accident Analysis \& Prevention, 42, 1894-1901.

Gustafson, P. (1997). Large Hierarchical Bayesian Analysis of Multivariate Survival Data. Biometrics, 53(1), 230-242.

Høye, A. (2016). How would increasing seat belt use affect the number of killed or seriously injured light vehicle occupants?. Accident Analysis \& Prevention, 88, 175-186.

Kim, H., Jung, K. Y., Kim, S. P., Kim, S. H., Noh, H., Jang, H. Y., ... \& Ju, J. M. (2012). Changes in preventable death rates and traumatic care systems in Korea. Journal of the Korean Society of Emergency Medicine, 23(2), 189-197.

Kopits, E., \& Cropper, M. L. (2005). Why Have Traffic Fatalities Declined in Industrialized Countries: Implications for Pedestrians and Vehicle Occupants. . World Bank Publications, 3678Law, T. H., Noland, R. B., \& Evans, A. W. (2011). The sources of the Kuznets relationship between road fatalities and economic growth. Journal of Transport Geography, 19(2), 355-365.

Noland, R. B. (2003). Medical treatment and traffic fatality reductions in industrialized countries. Accident Analysis \& Prevention, 35(6), 877-883.

Özkan, T., \& Lajunen, T. (2007). The role of personality, culture, and economy in unintentional fatalities: An aggregated level analysis. Personality and Individual Differences, 43(3), 519-530.

Pan, W. T. (2017). A newer equal part linear regression model: a case study of the influence of educational input on gross national income. Eurasia Journal of Mathematics, Science and Technology Education, 13(8), 5765-5773

Spoerri, A., Egger, M., \& von Elm, E. (2011). Mortality from road traffic accidents in Switzerland: longitudinal and spatial analyses. Accident Analysis \& Prevention, 43(1), 40-48

Taylor, N. L., \& Daily, M. (2019). Self-reported factors that influence rear seat belt use among adults. Journal of Safety Research, 70, 25-31

Todaro, M. P., \& Smith, S. C. (2015). Economic Development. United Kingdom: Pearson Education.

United Nations Development Programme. (2020a). Human Development Index (HDI). http://hdr.undp.org/en/content/human-development-index-hdi

United Nations Development Programme. (2020b). Human Development Data (1990-2018). http://hdr.undp.org/en/data 
Üzümcüoğlu, Y., Solmazer, G., Özkan, T. (2020). The relationship between culture and traffic fatality rates at national level: the moderating role of the economy. Trafik ve Ulaşım Araştırmaları Dergisi , 3(1), 28-38.

van Beeck, E. F., Borsboom, G. J., \& Mackenbach, J. P. (2000). Economic development and traffic accident mortality in the industrialized world, 1962-1990. International Journal of Epidemiology, 29(3), 503509.

Wangdi, C., Gurung, M. S., Duba, T., Wilkinson, E., Tun, Z. M., \& Tripathy, J. P. (2018). Burden, pattern and causes of road traffic accidents in Bhutan, 2013-2014: a police record review. International Journal of Injury Control and Safety Promotion, 25(1), 65-69.

World Health Organization. (2018a). Global Status Report on Road Safety 2018. https://www.who.int/violence_injury_prevention/road_safety_status/2018/en/

World Health Organization. (2018b, July 5). Disability-adjusted Life Years (DALYs). https://www.who.int/gho/mortality_burden_disease/daly_rates/text/en/

World Health Organization (2020, February 7). Road traffic injuries. https://www.who.int/news-room/fact-sheets/detail/road-traffic-injuries 


\section{Appendix}

Appendix 1

HDI Values, Dimensions and Traffic Road Fatality Rates

\begin{tabular}{|c|c|c|c|c|c|c|}
\hline Country & $H D I$ & $L E B$ & $E Y S$ & MYS & GNI & $T R F$ \\
\hline Afghanistan & 0.491 & 63.8 & 10.3 & 3.6 & 1766 & 15.1 \\
\hline Albania & 0.788 & 78.2 & 15.4 & 10 & 11534 & 13.6 \\
\hline Angola & 0.57 & 59.9 & 11.4 & 5.1 & 6051 & 23.6 \\
\hline Antigua and Barbuda & 0.772 & 76.6 & 12.5 & 9.2 & 20909 & 7.9 \\
\hline Argentina & 0.828 & 76.2 & 17.4 & 10.5 & 18249 & 14 \\
\hline Armenia & 0.751 & 74.6 & 13.2 & 11.7 & 8310 & 17.1 \\
\hline Australia & 0.935 & 83 & 22.9 & 12.6 & 43653 & 5.6 \\
\hline Austria & 0.909 & 81.3 & 16.1 & 12.6 & 44621 & 5.2 \\
\hline Azerbaijan & 0.749 & 72.5 & 12.1 & 10.5 & 15146 & 8.7 \\
\hline Bangladesh & 0.599 & 71.8 & 10.8 & 5.9 & 3620 & 15.3 \\
\hline Barbados & 0.814 & 78.9 & 15.3 & 10.6 & 15881 & 5.6 \\
\hline Belarus & 0.812 & 74 & 15.5 & 12.3 & 15997 & 8.9 \\
\hline Belgium & 0.915 & 81.1 & 19.7 & 11.8 & 42260 & 5.8 \\
\hline Belize & 0.722 & 74.2 & 13.5 & 9.7 & 7272 & 28.3 \\
\hline Benin & 0.512 & 60.9 & 12.6 & 3.6 & 2001 & 27.5 \\
\hline Bhutan & 0.61 & 70.8 & 12.1 & 3 & 8202 & 17.4 \\
\hline Bolivia (Plurinational State of) & 0.692 & 70.6 & 13.6 & 8.9 & 6535 & 15.5 \\
\hline Bosnia and Herzegovina & 0.765 & 77 & 13.9 & 9.7 & 11810 & 15.7 \\
\hline Botswana & 0.719 & 68.2 & 12.6 & 9.3 & 15353 & 23.8 \\
\hline Brazil & 0.757 & 75.2 & 15.4 & 7.7 & 13907 & 19.7 \\
\hline Bulgaria & 0.812 & 74.7 & 15.1 & 11.8 & 17757 & 10.2 \\
\hline Burkina Faso & 0.42 & 60.4 & 8.5 & 1.5 & 1582 & 30.5 \\
\hline Cabo Verde & 0.645 & 72.3 & 12 & 6.2 & 5989 & 25 \\
\hline Cambodia & 0.572 & 69 & 11.3 & 4.7 & 3248 & 17.8 \\
\hline Cameroon & 0.556 & 58.1 & 12.7 & 6.1 & 3229 & 30.1 \\
\hline Canada & 0.92 & 82.1 & 16.1 & 13.3 & 42691 & 5.8 \\
\hline Central African Republic & 0.372 & 51.6 & 7.6 & 4.3 & 732 & 33.6 \\
\hline Chad & 0.398 & 53.4 & 7.2 & 2.4 & 1836 & 27.6 \\
\hline Chile & 0.843 & 79.8 & 16.4 & 10.3 & 21776 & 12.5 \\
\hline China & 0.749 & 76.2 & 13.9 & 7.8 & 14311 & 18.2 \\
\hline Colombia & 0.759 & 76.7 & 14.6 & 8.3 & 13087 & 18.5 \\
\hline Comoros & 0.537 & 63.7 & 11.2 & 4.8 & 2504 & 26.5 \\
\hline Congo & 0.613 & 63.6 & 11.6 & 6.5 & 6765 & 27.4 \\
\hline Congo (Democratic Republic of the) & 0.453 & 59.7 & 9.6 & 6.6 & 794 & 33.7 \\
\hline Costa Rica & 0.789 & 79.7 & 15.4 & 8.6 & 14393 & 16.7 \\
\hline Croatia & 0.832 & 78 & 15.1 & 11.4 & 21216 & 8.1 \\
\hline Cuba & 0.771 & 78.6 & 14.1 & 11.6 & 7597 & 8.5 \\
\hline Cyprus & 0.869 & 80.5 & 14.7 & 12.1 & 31358 & 5.1 \\
\hline Czechia & 0.885 & 78.9 & 16.8 & 12.7 & 29211 & 5.9 \\
\hline Denmark & 0.928 & 80.6 & 19.1 & 12.6 & 47729 & 4 \\
\hline Dominica & 0.729 & 77.9 & 13.1 & 7.8 & 10179 & 10.9 \\
\hline Dominican Republic & 0.738 & 73.5 & 14.1 & 7.9 & 13801 & 34.6 \\
\hline Ecuador & 0.756 & 76.4 & 14.9 & 9 & 10208 & 21.3 \\
\hline Eritrea & 0.434 & 65.1 & 5.4 & 3.9 & 1627 & 25.3 \\
\hline Estonia & 0.875 & 78.1 & 16.1 & 13.1 & 27915 & 6.1 \\
\hline Eswatini (Kingdom of) & 0.596 & 57 & 11.4 & 6.7 & 9457 & 26.9 \\
\hline Ethiopia & 0.46 & 65.5 & 8.7 & 2.7 & 1612 & 26.7 \\
\hline Fiji & 0.718 & 67.2 & 14.4 & 10.8 & 8588 & 9,6 \\
\hline Finland & 0.922 & 81.4 & 19.3 & 12.4 & 40609 & 4.7 \\
\hline France & 0.887 & 82.3 & 15.5 & 11.4 & 38926 & 5.5 \\
\hline Gambia & 0.456 & 61.2 & 9.2 & 3.5 & 1416 & 29.7 \\
\hline Georgia & 0.776 & 73.2 & 15 & 12.8 & 8768 & 15.3 \\
\hline Germany & 0.936 & 80.9 & 17.1 & 14.1 & 45577 & 4.1 \\
\hline Ghana & 0.587 & 63.1 & 11.6 & 7.1 & 3756 & 24.9 \\
\hline Greece & 0.866 & 81.7 & 17.3 & 10.3 & 24187 & 9.2 \\
\hline Grenada & 0.76 & 72.4 & 16.9 & 8.7 & 11650 & 9.3 \\
\hline Guatemala & 0.648 & 73.5 & 10.7 & 6.4 & 7199 & 16.6 \\
\hline Guinea & 0.456 & 60.2 & 9 & 2.7 & 1971 & 28.2 \\
\hline Guinea-Bissau & 0.457 & 57.3 & 10.5 & 3.3 & 1570 & 31.1 \\
\hline Guyana & 0.666 & 69.5 & 11.5 & 8.4 & 7294 & 24.6 \\
\hline Honduras & 0.618 & 74.7 & 10.2 & 6.5 & 4032 & 16.7 \\
\hline Hungary & 0.838 & 76.3 & 15.1 & 11.8 & 25081 & 7.8 \\
\hline Iceland & 0.932 & 82.6 & 19.2 & 12.4 & 44809 & 6.6 \\
\hline India & 0.637 & 68.9 & 12.3 & 6.4 & 6075 & 22.6 \\
\hline Indonesia & 0.7 & 71 & 12.9 & 8 & 10419 & 12.2 \\
\hline Iran (Islamic Republic of) & 0.799 & 76 & 14.9 & 10 & 18710 & 20.5 \\
\hline Iraq & 0.672 & 70.1 & 10.1 & 6.9 & 16387 & 20.7 \\
\hline Ireland & 0.936 & 81.6 & 18.8 & 12.5 & 50911 & 4.1 \\
\hline Israel & 0.902 & 82.5 & 15.9 & 13 & 32428 & 4.2 \\
\hline Italy & 0.878 & 83 & 16.2 & 10.2 & 34818 & 5.6 \\
\hline Jamaica & 0.722 & 74.2 & 13.1 & 9.7 & 7721 & 13.6 \\
\hline Japan & 0.91 & 84.1 & 15.2 & 12.7 & 39407 & 4.1 \\
\hline Jordan & 0.722 & 74.2 & 11.9 & 10.4 & 8253 & 24.4 \\
\hline Kazakhstan & 0.808 & 72.1 & 15 & 11.7 & 22062 & 17.6 \\
\hline Kenya & 0.568 & 65.4 & 11 & 6.4 & 2875 & 27.8 \\
\hline Kiribati & 0.622 & 67.6 & 11.8 & 7.9 & 3985 & 4.4 \\
\hline Korea (Republic of) & 0.901 & 71.7 & 16.4 & 12.2 & 35122 & 9.8 \\
\hline Kuwait & 0.809 & 82.4 & 13.8 & 7.2 & 76145 & 17.6 \\
\hline Kyrgyzstan & 0.669 & 75.2 & 13.4 & 10.9 & 3108 & 15.4 \\
\hline Lao People's Democratic Republic & 0.598 & 71.1 & 11.2 & 5.2 & 5748 & 16.6 \\
\hline
\end{tabular}

www.nesnedergisi.com 


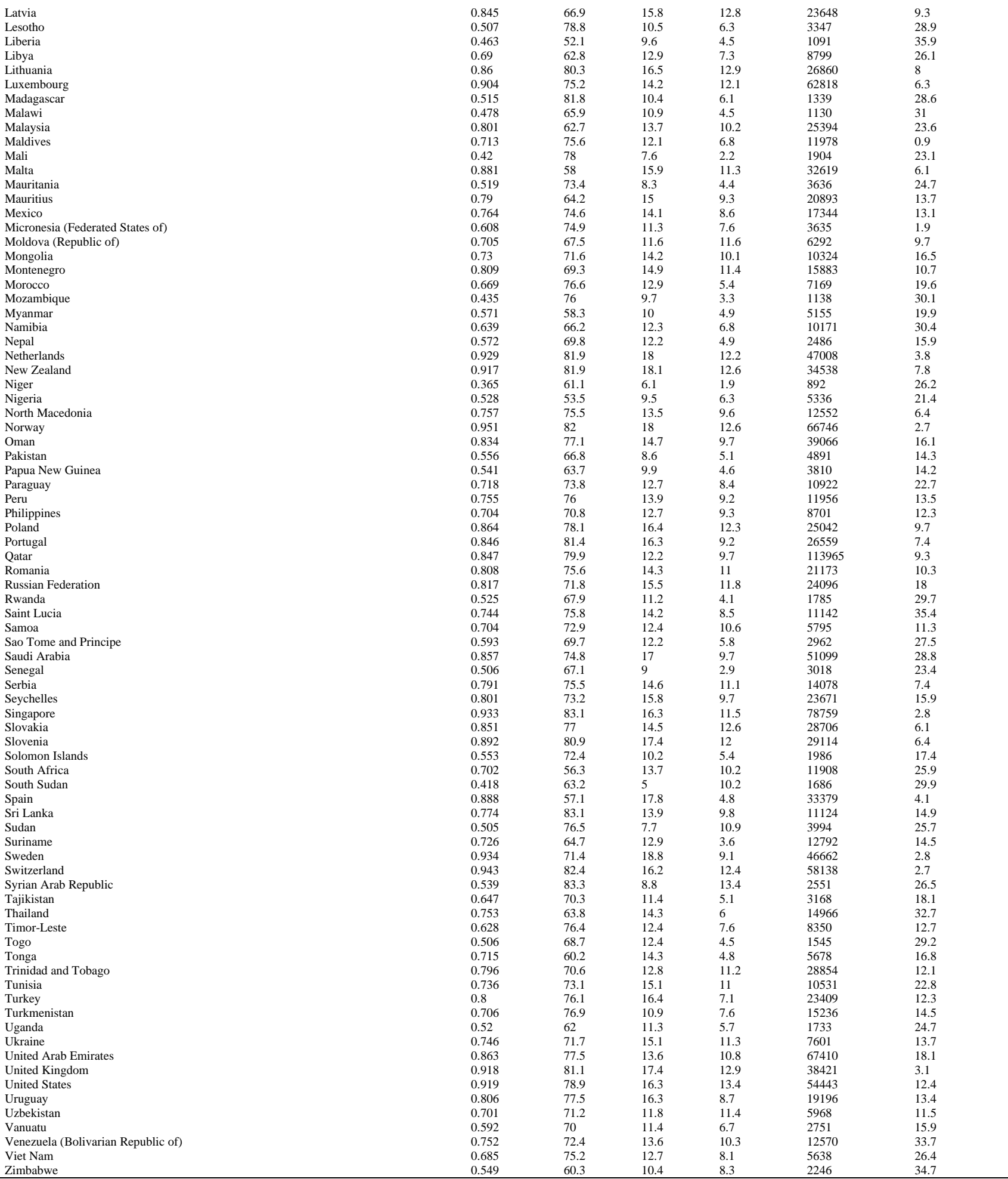

